\title{
Why Does He Choose Home Schooling?
}

\author{
Evi Winingsih, Frida Putri Wardhani \\ Department of Guidance and Counseling \\ Universitas Negeri Surabaya \\ Surabaya, Indonesia \\ eviwiningsih@unesa.ac.id
}

\begin{abstract}
The purpose of this study is to determine the factors that encourage individuals to choose homeschooling. The emergence of homeschooling helps many students in completing primary to secondary school education. There are many things that encourage students to prefer the informal school. This research uses the case study method. The research subjects were active students in one of the homeschooling in Surabaya. This research uses a qualitative method by collecting data using interviews and analyzed descriptively. The results of this study indicate that bullying is one of the factors causing children or adolescents to choose education in homeschooling rather than in formal educational institutions. Bullying makes children more uncomfortable to go to school, bullying victims feel insecure if they are constantly in the school environment. The rise of bullying cases that occur in school-age children is currently very alarming. Even cases of bullying are a phenomenon that often occurs in schools. In addition to bullying, the overly rigid school regulations also reinforce students' reasons for choosing homeschooling. the inability of to adapt to school rules will be a serious problem.
\end{abstract}

Keywords-bullying; homeschooling

\section{INTRODUCTION}

The rise of cases of violence that occur in school-age children is currently very alarming. The phenomenon of violence in children that often occurs in schools today is bullying. Bullying can be in the form of ridicule, ridicule. exclusion, beating, kicking or pushing. Bullying behavior is a form of behavior that is feared by school-age children. That is because bullying is a very disturbing form of behavior [1]. Soendjojo [2] said that students who experience bullying are students who have a low level of assertiveness. Individuals who have a low level of assertiveness tend to have irrational fears. This form of irrational fear can be anxious behavior and the inability to defend his personal rights. Likewise, victims of bullying, they are less able to show attitude against the perpetrators. Lack of resistance makes bullying perpetrators always want to bullying victims.

Bullying is repetitive aggression, which is done by someone or more with the intention of physically hurting or disturbing others (hitting, kicking, pushing, taking or seizing something that belongs to someone else), verbally (mocking, threatening) or psychologically (removing from the group, isolating, spreading gossip) [3]. Bullying is a part of acts of aggression repeatedly carried out by a person or child who is stronger against children who are weaker psychologically or physically [4]. Sullivan [5] said that bullying is an act of aggression that is carried out calmly or without a burden, deliberate and repetitive to attack a weak victim or someone who cannot defend themselves. So, it can be concluded that bullying is an aggressive behavior carried out repeatedly repeated by one child against a weaker child who intends to hurt physically and psychologically. Characteristics of victims can be divided into five, among others [6]:

\section{a. Academic character}

Academically, victims look less intelligent than people who are not victims or vice versa.

\section{b. Social Character}

Socially, victims appear to have a closer relationship with their parents.

\section{c. Mental character}

Mentally or victim's feelings see themselves as ignorant and worthless people. Their confidence is low, and their level of social anxiety is high. Signs such as anxiety, depression, and mental stress are often present in victims.

\section{d. Physical character}

Physically, the victim is a weak person, and bullies take the opportunity. Executant of bullying also targets people who have certain physical weaknesses. Bullies often target victims who are disabled, overweight, generally not physically attractive. Male victims are more often subjected to torture directly, for example physical bullying, compared to male victims, female victims are more often subjected to indirect torture, for example through words or verbal bullying.

e. Character between individuals

Although victims of bullying are eager for social acceptance, they rarely start activities that lead to social direction. Children who are victims of bullying are less considered by the coach, because victims of bullying are not active in an activity.

If bullying lasts for a long time, it can affect students' selfesteem, increase social isolation, lead to withdrawal behavior, make adolescents vulnerable to stress and depression, and the insecurities felt by victims [7]. A student can be said to have experienced bullying if exposed to bullying repeatedly and all the time on negative actions by one or more other students [8]. The definition of bullying victim is someone who gets repeated 
aggression from peers both physically and verbally, even attacks can be psychological violence.

The results of research conducted by Widayanti and Siswati [9] show that $37.55 \%$ of students are victims of bullying. $42.5 \%$ of students suffered physical bullying and $34.06 \%$ of non-physical bullying. Papalia [10] explained that the most extreme thing about the psychological impact of bullying is the emergence of psychological disorders such as excessive anxiety, feeling pain, depression, and having the desire to commit suicide and the appearance of symptoms of posttraumatic stress disorder. A student can be said to have experienced bullying if exposed to bullying repeatedly and all the time on negative actions by one or more other students [11]. Bullying can be a threatening threat to adolescents because acceptance from peers is very important so that exclusion can be interpreted as stress, frustration, and sadness [12].

The bullying behavior is feared by school age children while in the school environment. Though schools should be a safe and comfortable place to learn and gain useful knowledge. So that bullying behaviors becomes a scourge for school-age children to attend formal education institutions. Therefore, this allows some children or adolescents to prefer attending school in non-formal educational institutions such as home-schooling.

The term home schooling itself comes from English means home schooling. Home-schooling is rooted and growing in the United States. Home-schooling is also known as home education, home based learning or independent schools. The general understanding of home schooling is an educational model in which a family chooses to take responsibility for their children's education by using the home as their educational base. According to Stevens [13], home schooling or home schooling, is an activity to educate children at home in full. According to Greenwalt [14] said that home-schooling will teach children with a variety of conditions and situations, and a social environment that continues to develop. In the United States, a National Centre of Education Statistics survey was conducted on the reasons a family chooses home-schooling. From the survey, it can be seen the 3 highest reasons, families choose home-schooling.

\section{METHOD}

This study uses a qualitative design. Qualitative research is a research process that is done naturally according to the state of objects in the field, and the type of data collected is qualitative data. The object in this study is a phenomenon that exists and is happening in the field. In qualitative research, researchers go directly to the field to obtain data and understand and study situations in the field related to the reason's students choose home schooling. The design of this study uses the case study method. In this research the case study used is a case study with a single case. Sources of data in this study were students who took home schooling in one of the home schooling programs in Surabaya.

Data collection techniques used in this study were interviews. According to Miller and Crabtree [15], interview is a data collection technique by asking questions verbally and answering respondents directly, verbally. In this interview process the researcher will collect data about the reason's students choose home schooling rather than formal education.

\section{RESULTS AND DISCUSSION}

Data obtained from the interview show that the resource person with the initials AL is 17 years old who came from Jombang. Currently the student is pursuing a class XI education majoring in Natural Sciences at home schooling. At home schooling, AL is taking a distance learning program, which is a learning program that brings mentors or teaching staff who come to the house to teach at students' homes. Because AL comes from Jombang which in fact the area is very far away if reached from Surabaya, so it is not possible if AL must come every day to home schooling in Surabaya. Therefore, AL prefers to attend distance learning programs. But for every Friday or if the parents have a job in Surabaya, AL will come to home school and study there.

When AL interviewed said that before schooling in home schooling, AL had attended formal education institutions. The reason AL chose to go to school at home schooling was that AL had been a victim of bullying when he went to a formal education institution. AL decided to go to home schooling when he was in eighth grade (8) Middle School. In the case of bullying experienced by AL, it started when he was in 5th grade of elementary school. Cases of bullying experienced by AL were verbal and physical bullying. Bullying experienced by AL often makes AL not go to school. Even when graduating 6th grade, AL did not go to school for one year and entered school at the time of the national examination of elementary school graduation. AL has experienced Bullying since fifth grade (5) until graduated elementary school even when AL entered the Middle School.

The bullying case experienced by AL occurred during the Middle School AL. AL repeatedly moved schools from one school to another. The AL is increasingly uncomfortable going to school and experiencing depression. Because of this AL's parents took the initiative to bring AL to psychologists and psychiatrists for consultation. After consulting, the parents and AL themselves agreed to choose home schooling and take distance learning programs.

Bullying itself as a form of aggressive action is a worldwide problem. Bullying behavior is very vulnerable to occur in young men and women students. According to the context, bullying behavior can occur in various places, ranging from the educational environment or school, workplace, home, neighborhood, etc. What happens a lot now is the bullying behavior that occurs in the school environment. Both at the elementary school, junior high school, and high school. This might happen because bullying is often considered trivial. As happened to AL, began experiencing bullying when he was in 5 th grade of elementary school.

Forms of bullying behavior vary. Olweus [8] states that there are two forms of bullying, namely direct bullying and indirect bullying. Direct bullying is carried out against others through physical contact directly or verbally through open attacks such as threatening, encouraging, and pinching [8]. Indirect bullying or can be referred to as relational bullying is a closed aggressive behavior that intends to damage social 
relations owned by victims of bullying such as the spread of gossip, spreading issues, and removing victims from association [16]. These things are also experienced by AL when it becomes a victim of bullying which causes $\mathrm{AL}$ to experience depression

Bullying becomes a very disturbing behavior and is feared by children or teenagers. Moreover, bullying occurs in a school environment that should be a safe and comfortable place for learning for children and / or adolescents. This is a consideration $\mathrm{Al}$ chose to home school as a place for learning rather than formal educational institutions.

The purpose of home schooling itself is to serve students in the completion of education by creating conditions for a conducive learning environment, in the context of real life, overcoming limitations, weaknesses, and emotional obstacles faced by children, as well as developing talents, potentials possessed by equipping children to be able to solve problems its environment. In this case the purpose of home schooling is to overcome emotional barriers faced by children, in accordance with the AL problems that are currently experiencing bullying. This becomes the AL basis for choosing home schooling.

Home schooling is implemented in several forms namely single home schooling, multiple home schooling, and homeschooling communities. According to Greenwalt [14], the application of home schooling depends on the needs of each home schooler and is adjusted to the ability of parents and children's interests. AL chose a single home schooling where learning was done at home. But occasionally $\mathrm{AL}$ also follows community home schooling.

In addition to some of the reasons above, AL also said why he chose home schooling. Among them, because he felt comfortable studying at home schooling. According to him, the learning that was carried out was also more flexible and was not bound by the strict regulations like in formal education institutions. Interaction with teachers is also more relaxed, not feeling rigid and afraid of being scolded by teachers like in school. The validity of a set of rules that are very binding, the application of discipline that is too rigid, and the learning atmosphere that is too formal without realizing it often burdens and stifles the creativity of students in this case especially AL. In addition, the competition between students causes some students to feel stressed so that children see learning more as an obligation and a burden, not as a necessity. At school, the learning schedule has been determined and uniform for all students. On home schooling flexible learning schedules, depending on the agreement between the child and parents. Clothing worn at school is more relaxed. Not tied to special uniforms as is the case in formal education institutions.

The violence experienced by Al had a big impact on his life. So, in the end he chose to carry out homeschooling. The impact of bullying physically can be cured quickly. But the psychological impact that results will be more difficult to cure. Stress or even depression which then results in trauma about something. The fear arising from this bullying will result in students experiencing many things ranging from mild stress to depression [6]. This level of stress will affect the child's behavior. Starting from not confident, isolating themselves from the environment, even experiencing stagnation.

Some people consider Home-schooling to be an escape from a problem. Home-schooling is a place where people are unable to solve problems. But some others assume that homeschooling is one of the alternative limitations that individuals have [17]. Home schooling presents a more familial and private feel. Maybe for some people with home schooling the level of child socialization will decrease. More than that homeschooling presents solutions to take alternative education for students.

Al took the decision to continue Education at home schooling is a good choice. He was able to rise from the perpetrators of bullying by continuing education in homeschooling. Many victims of bullying remain in formal education with the consequences of suffering from bullying. There are also students who are unable to bullying and then choose to drop out of school. And they did not continue their education both formal and nonformal.

Home schooling education is not merely making children spoiled or lazy but trying to make children more independent because of the independence aspect which is an important aspect in children. Home-schooling education helps develop optimal potential both in knowledge, skills, attitudes, and personality by emphasizing the mastery of knowledge, functional skills, and attitude development, as well as professional personality while expanding access to primary and secondary education.

\section{CONCLUSION}

Education is the right of every individual. Every person has the right to choose the desired education model and in accordance with their individual circumstances. Choosing homeschooling as a forum for children or adolescents who have problems with formal education institutions is the right choice to support children or young people learning comfortably and safely. One of the problems faced by students in school is bullying. Bullying is a behavior that is very disturbing and becomes a behavior that is feared by children or adolescents when attending school. Even this behavior is a scourge of students while at school. What should be a school is a comfortable and safe place as a place for children or adolescents to gain knowledge.

Bullying can be psychological for victims who experience it. Can cause anxiety and depression and even withdraw from the social environment. So that if bullying behavior continues to occur at school, then students who are victims of bullying will be increasingly uncomfortable to study at school. The bad effects of children become afraid to get into school. Therefore, this bullying behavior is one of the reasons children and parents prefer homeschooling as a place of learning rather than choosing formal educational institutions.

\section{REFERENCES}

[1] D. Tattum and E. Tattum, "Bullying: A whole-school response," in Learning to behave, Routledge, 2017, pp. 67-84.

[2] D. Soendjojo, "Mengajarkan Asertifitas Pada Remaja," J. Psikol., vol. 
4, no. 3, pp. 5-7, 2009.

[3] Y.-Y. Cheng, L.-M. Chen, H.-C. Ho, and C.-L. Cheng, "Definitions of school bullying in Taiwan: A comparison of multiple perspectives," Sch. Psychol. Int., vol. 32, no. 3, pp. 227-243, 2011.

[4] R. M. Kowalski and S. P. Limber, "Psychological, physical, and academic correlates of cyberbullying and traditional bullying," $J$. Adolesc. Heal., vol. 53, no. 1, pp. S13-S20, 2013.

[5] K. Sullivan, The anti-bullying handbook. Sage, 2010.

[6] R. Ortega, P. Elipe, J. A. Mora-Merchán, J. Calmaestra, and E. Vega, "The emotional impact on victims of traditional bullying and cyberbullying: A study of Spanish adolescents," Zeitschrift für Psychol. Psychol., vol. 217, no. 4, pp. 197-204, 2009.

[7] S. B. Matthiesen and S. Einarsen, "Perpetrators and targets of bullying at work: Role stress and individual differences," Perspect. Bullying Res. Childhood, Work. Cyberbullying, vol. 22, no. 6, p. 135, 2015.

[8] D. Olweus, "A useful evaluation design, and effects of the Olweus Bullying Prevention Program," Psychol. Crime Law, vol. 11, no. 4, pp. 389-402, 2005.

[9] C. G. Widayanti and S. Siswati, "Fenomena bullying di sekolah dasar negeri di semarang: sebuah studi deskriptif," Junal Psikol. Undip, 2009.

[10] D. Papalia, Experience human development. McGraw-Hill Higher Education, 2014.

[11] G. R. Gredler, "Olweus, D.(1993). Bullying at school: What we know and what we can do. Malden, MA: Blackwell Publishing, 140 pp., \$25.00.," Psychol. Sch., vol. 40, no. 6, pp. 699-700, 2003.

[12] J. W. Santrock, "Adolescence perkembangan remaja," Jakarta: Erlangga, pp. 422-424, 2003.

[13] M. L. Stevens, Kingdom of children: Culture and controversy in the homeschooling movement, vol. 37. Princeton University Press, 2009.

[14] K. Greenwalt, "Home/schooling our children," in Home/Schooling, Springer, 2016, pp. 95-108.

[15] W. L. Miller and B. F. Crabtree, "Depth interviewing," Approaches to Qual. Res. A Read. theory Pract., pp. 185-202, 2004.

[16] M. F. Catanzaro, "Indirect aggression, bullying and female teen victimization: A literature review," Pastor. Care Educ., vol. 29, no. 2, pp. 83-101, 2011.

[17] L. Holzman, Schools for growth: radical alternatives to current education models. Routledge, 2016. 